\title{
Bureaucratic Policy and Legal Aspects of Societal Engagement in Latvian National Defense
}

\author{
Ma. sc. pol. Olevs Nikers \\ Rìga Stradiňš University, \\ Doctoral Programme "Political Science", Latvia \\ Olevs.Nikers@gmail.com
}

\section{Abstract}

In perfectly functioning democratic civil society, political decisions should be based on competence of elected officials and their knowledge of certain political issues where experts play an important role. The aim of this article is (1) to look at the role of elected officials (legislators) and public administration institutions in determining the governance of rule of law within defense policy in relation to engagement of the members of society in national defense, and (2) to analyse what factors affect sustainability of this policy and under what circumstances it transforms, and how this transformation is reflected in the public law.

Methodologically theoretical / literature overview has been conducted, discussing the role of institutions in the political process and their interaction with legislator within the framework of new institutionalism. Empirically the case of Latvian defense policy towards societal engagement into national defense has been presented and analysed. An important aspect of the empirical study of this issue is interaction among the legislator, public administration institutions, non-governmental sector, and the public. Findings of this analysis leads to argument that Latvian ministry of defense plays a central role in sustainability and transformation of the national policy towards societal engagement into national defense. Legislator does not take necessary initiative in these policies, which is reflected in absence of needed amendments from the perspective of the public law, considering political ambition set by the Ministry of Defense of Latvia.

Required political support of ministry's political initiatives have been granted by the parliament, but as a consequence, this policy in its full extent is not currently properly reflected in the legal acts and regulations.

Keywords: legislation, public law, national defense, institutionalism, bureaucratic policy, decision making, public administration, parliamentarism. 


\section{Introduction}

Public engagement in the national defense is first and foremost a matter of public law. The Constitution of the Republic of Latvia enshrines independence, freedom and democratic state system of the state. Presently, the persons who are involved in the provision of state defense are very clearly defined in the law. Article 5 of the National Security Law stipulates that every Latvian citizen has a duty to engage in national defense (Nacionālās drošỉbas likums, 2001). Politicians decide how to ensure the participation of citizens in strengthening national security and, if necessary, in national defense, and implementation of this policy is entrusted to public administration, which in case of defense policy is the Ministry of Defense and the National Armed Forces.

After abolition of compulsory military service in 2007, the laws and regulations established two possibilities for the participation of citizens in the national defense professional military service in the National Armed Forces (Nacionālo bruṇoto spēku likums, 1999; Militārā dienesta likums, 2002) and voluntary service in the National Guard (Zemessardzes likums, 2010). In the domain of extra-curricular education, young people have the opportunity to get involved in the Youth Guard. Despite the fact that public, politically elected officials and the Ministry of Defense (hereinafter - MoD) itself have conceptually defined the need and obligation for the public to participate more widely and actively in national defense, the legal framework governing engagement of residents and Latvian citizens in public defense from a legal point of view has remained essentially unchanged.

Dynamics of defense policy endurance and change in both theory and practice are determined by such factors as national threat assessment and changes in the international security situation, participation in international security alliances, setting domestic political priorities and distribution of material resources, competence and involvement of decision-making bodies, and the capacity of the public administration.

Professional and academic literature so far has developed an understanding of how Latvia's membership in the North Atlantic Treaty Organization (NATO) has affected national defense policy. The aim of this article is to take a closer look at theoretical and practical aspects that have determined dynamics of defense policy or its stagnation during Latvia's accession to NATO and how this has been reflected in legislation.

Although political debate in the field of defense often takes place in narrow forums of professionals and decision-makers, the issue of public engagement in the national defense covers the widest range of actors involved in policy-making and implementation. The study of the issue of public engagement in national defense best reveals interaction of the political, bureaucratic and public sectors in determining the sustainability of this policy, legislation and understanding of the processes that lead to transformation of these policies.

The first section of the article provides a brief review of institutionalist literature that provides a theoretical understanding of these issues, looking at the role and 
challenges of institutions in a democratic society, while the second and third section examine bureaucratic, political and legal aspects and dynamics of public engagement in national defense.

\section{Institutions in Democratic Society}

Theory of new institutionalism emphasises phenomenon of societal and individual impact over a political system and its different powers (Easton, 1953). In certain areas of public administration, institutions enjoy greater public trust and feedback than the others. Defense sector usually is one of the most "trusted" branches of public administration, as long as it is capable of implementing a policy in the interests of national security, which, is adequately reflected in the national legislation.

Interaction between the legislature and bureaucratic policy in the various dimensions of policymaking retains a great deal of interest among researchers in both legal sciences and research within comparative politics and public administration. To define the role of the institution in a democratic society, this section will provide a brief overview of theoretical approaches in state governed bureaucratic organisations as defined by rule of law.

According to the theory of new institutionalism, public administration institutions tend to create their own "business" environment with respect to other parties acting in policy-making and legislation (Thoenig, 2011). Although ideally public administration should be guided by the legislator and public vision that is translated into specific policy projects, public administrations establish a degree of "autonomy" and often determine not only the legislator's agenda but also the content and substance of the policy. The issue of "autonomy" of the branches of public administration is also relevant in the case of Latvia, as Article 6 of the Law of Public Administration stipulates that "public administration is organised in a unified hierarchical system [and] no institution or administrative official may function outside this system" (Valsts pārvaldes iekārtas likums). However, institutions tend to evolve from policy "instrumentalisationists" to "conceptualisers": they generate and implement "policy recipes" that determine how the "game is played" (Hammond, 2003).

Mechanisms of public administration influence the course of individual and public thinking, interpret the facts, act in accordance with their regulations, as well as engage in solving public disputes. Researchers sometimes ask whether the activity of public administration always meets the needs of society and whether it promotes democratic participation. In a legal and democratic society, the very idea that technocracy can determine and control public opinion by "compromising" the legislature's ability to pass laws that serve the best interests of society is not acceptable.

One theoretical approach of the new institutionalism is based on the idea that political choices are made in the process of institution-building or policy-making, and it has a sustainable impact on future decision-making, also called a "path dependence" 
that describes "ancient" routes of the presently made decisions (Pierson \& Skocpol, 2002; Krasner, 1984).

Culture, experience, competence and vision of the bureaucratic mechanism are placed in the laws and regulations, as far as the legislator allows. Changes in bureaucratic policy routines can often be driven by the influence of external forces, necessitating change and adaptation. It is also a question of predictability of public administration and the search for logic, underlying one or another activity, or rather it is a kind of compromise between the content of the problem to be addressed by officials and the level of uncertainty at the time of decision-making (Peters \& Pierre, 2011).

According to Jean-Claude Thoenig, public administration is involved in policymaking. Empirical research here considers three basic dimensions or aspects: (1) different goals of the actors involved, (2) the way information is consolidated, (3) administrative capacity and choice of decision-making processes (Thoenig, 2005). Thus, public administrations act as a political "arena" of force and balance with the "big policy" makers and legislators.

This raises an important question regarding functioning of the bureaucratic mechanism in a democracy: how successfully institutions are integrated into democratic systems, reflecting the nature of democratic decision-making and policy implementation, especially in the field of defense policymaking?

In the course of the development of democracy, society has taken over political power from the hands of autocrats and bureaucrats and handed it over to the elected political representatives (Cooper, Gvosdev \& Blankshain, 2018). According to Thomas Hammond, the irony of twentieth-century public administration is that as social and economic responsibilities of democratic governments increase, elected officials are delegating increasing policymaking powers to career officials, returning real political power to technocrats. It would not be an exaggeration to say that bureaucrats in liberal democracies are able to act independently of elected officials. In any case, bureaucracy often has some independent policymaking capacity, whether delegated or not. It is therefore important to create conditions in which bureaucrats are given a greater or lesser role in policymaking and the legislative process in a democratic environment.

One of the main criteria for significance of public service establishment in democratic system is the degree to which legislator is able to exercise control over governmental officials. For example, according to Aberbach and Rockman, in the United States (U.S.) it is a commonsense, that the U.S. Federal Reserve is capable and eligible to operate independently from the Congress, as it shapes U.S. monetary policy, unlike, the International Development Agency of Department of Agriculture which deals with specific international aid projects (Aberbach \& Rockman., 2000; Nikers \& Tabuns, 2019).

Different levels of bureaucratic autonomy can have important political consequences. The reason is that the political choices of officials do not always reflect priorities of elected officials. 
Rebecca Ingber suggests that after the 2016 U.S. presidential election term of a "deep state" emerged in American political terminology. This approach is related to allegation that body of permanent bureaucratic officials work "behind the scenes" to determine U.S. national security policy according to their preferences, ignoring the president and their administration (Ingber, 2018).

There are two main reasons why officials could develop independent policymaking capacity. One of the reasons given by Max Weber is that officials can often be more competent in certain matters than elected officials. Even if officials are not granted policymaking rights, they have access to more information and are endowed with a deeper theoretical understanding and operational experience that can enable them to act independently. Most discussions on bureaucratic autonomy involve asymmetries in information, understanding and competence; less attention is paid to the bureaucratic autonomy that can arise in disputes between elected officials and the public administration system (Nikers \& Tabuns, 2019). Another argument why bureaucracy can develop its ability to act independently is associated to its relative "symbiosis" towards elected officials, who are interested in expertise and professional knowledge, which civil servants can provide for politicians, so that legislator would be more capable to perform better politics (Cooper, Gvosdev \& Blankshain, 2018; Nikers \& Tabuns, 2019).

Empirical research of these issues in the case of Latvia is relevant in the context of political debate and bureaucratic policy, which is reflected on the one hand in public policy models and policy initiatives, and, on the other hand, in legislation, which is the end result of interaction between elected officials and bureaucratic policy.

\section{Sustainability of Bureaucratic Policy}

Within three years after Latvia's accession to NATO (2004), compulsory military service was abolished, and a fully professional National Armed Forces was established. Such a policy was determined both by Latvia's accession to the North Atlantic Treaty Organization, Article 5 of which, as it was explained to the public by governmental officials and elected representatives, promised guaranteed support in the event of a military attack, and public "fatigue" from compulsory military service as it was experienced during the Soviet occupation.

During this time, society at large, in obedience to the advice of public administration and politicians, voluntarily "withdrew" from active participation in strengthening national defense, leaving it to politicians, officials and army professionals. The changes gradually appeared only after Russia's aggression in Ukraine in the spring of 2014, but from the point of view of law and legislation, the situation regarding public engagement in national defense has not changed substantially since abolition of compulsory military service in 2007.

There are several levels of national and international significance that influence how defense and security policy is defined, as well as legislation within the national 
security domain. Foreign assistance and advice, mainly from Northern Europe, played an important role in the early stages of rebuilding of the defense forces in the 1990s, influencing Latvia's defense and security system and setting the course for Latvia's membership in NATO and transitioning to professional military service.

The most significant reform of the defense sector took place after 2000, when Latvia received guidelines or the so-called "road map" for joining NATO, which required the renewal and restructuring of the military sector and the amendment of laws in accordance with NATO standards. Although Latvian defense system has experienced a number of positive trends, it still faces many challenges, including public engagement in strengthening national security (Nikers, 2019).

After the restoration of independence, formation of Latvia's defense and security can be divided into three stages.

Latvia gradually established its army and defense system, adapting to the existing international environment and relying on the norms of international law after the end of the Cold War. Shortly after the restoration of independence, political and economic integration in the Western political and economic space became the main driving force of Latvia's domestic and foreign policy. At the same time, military development was somewhat neglected, with only a few units maintained, mainly to participate in international peacekeeping operations. In this phase, the "Russian threat" was assessed as relatively low, given the significant domestic political problems in Russia. The defense forces of all the Baltic States reflected this situation, as a result of which only symbolic military forces remained in Latvia (Nikers, 2019).

The second stage in the process of Latvia's defense and security development in the early 2000s and resulted from Latvia's membership in NATO in 2004. The NATO Membership Action Plan called for changes in the command and control of the Latvian defense system. In addition, military personnel were completely reformed and reorganised according to the NATO standards. During this period, compulsory military service (CMS) was abolished in Latvia and Lithuania.

Occupation and annexation of Crimea by Russia in 2014 led to changes in Latvia's defense concept (Par valsts aizsardzības koncepcijas apstiprināšanu, 2016). Simultaneously, much more attention was paid to the weak spots in NATO's collective ability to protect the Baltic States under Article 5 of the NATO Treaty. These include: (1) the presence of Russian military forces in the region (Kaliningrad), and the vulnerability of the Suwałki Corridor, (2) the presence of massive Russian military forces against the smaller Baltic armies acting as the armies of the most militarily powerful NATO nations; and (3) the location of NATO capabilities far from the potential defense positions of the Baltic states (Nikers, 2019).

Since Latvia adopted policies towards integration in EU and NATO, legislator often acted as a "mailbox", receiving guidelines and instructions provided by the officials of ministry of Foreign Affairs and Ministry of Defense and approved a number of legal acts according to these "pre-set" conditions in a way for Latvia to fulfill political and legal 
obligations in joining these international organisations. This tradition of "competence" and "older brother" in cooperation with the legislature has continued even after successful accession to NATO. The legislator usually follows recommendations of MoD officials and NAF professionals, which are also reflected in the law (Nikers \& Tabuns, 2019).

\section{Policy Transformation and Legal Aspects}

After the Russian aggression in Ukraine, at the level of public administration and among elected officials, the notion that the state must increase its self-defense capabilities gradually began to crystallise, and the notion of wider public engagement in national defense was returned to governmental agenda, which was later reflected in legislation as well.

In general, the response to international development from the side of Latvian Ministry of Defense and the legislator regarding public engagement in national defense was relatively slow.

The Concept of National Defense, which is approved by the Saeima, the Parliament of Latvia, in accordance with Article 29 of the National Security Law at least once during each parliamentary term, was updated only within two years after the Russian aggression in Ukraine provides understanding of changes within international security environment, but is not giving sound and clear guidance on comprehensive public engagement in national defense (Par valsts aizsardzïbas koncepcijas apstiprināšanu, 2016). Consequently, as the National Defense Concept is updated every four years, in this situation there was no public conviction among defense policy makers that Russia's aggression in Ukraine would serve as a basis for updating the concept earlier than the provisional deadline.

Only in the second half of 2018, more than four years after the Russian aggression in Ukraine, the MoD began work on strengthening and incorporating the Comprehensive National Defense System in laws and regulations - a conceptual approach to engage all public administration institutions in national defense and setting ambition for a wider public involvement in national defense in the future. The informative report on the "Implementation of the Comprehensive National Defense System" (Informativais ziṇojums par visaptverošās sistēmas ieviešanu Latvijā) was approved by the Latvian Cabinet of Ministers on January 8, 2019. This approach was chosen as an alternative to the resumption of compulsory military service and was based on engagement of all public administration branches in ensuring the national defense. Amendments to the National Security Law (Nacionālās drošības likums) regarding comprehensive state defense entered into force on October 30, 2018.

Wider public discussions on resumption of compulsory military service began in the spring of 2016. Then, according to the results of the SKDS survey, the number of supporters of compulsory military service had increased significantly. The survey showed that almost half of the Latvian population supports CMS (Meisters, 2016). At that time, the Minister of Defense Raimonds Bergmanis rejected resumption of the compulsory 
military service, citing excessive expenses in the state budget for the implementation of such a policy. The head of the Saeima Defense Commission Ainars Latkovskis rejected the possibility of CMS for the same reason. In her turn, the Speaker of the Saeima Ināra Mürniece called to resume the discussion on the necessity of the CMS, pointing to the renewal of conscription in Lithuania which took place in spring of the same year, but a year later I. Mürniece announced that the CMS should be renewed after the reform of the defense sector (Rìta panorāma, 06.04.2016).

During 2017, the MoD put emphasis on the development of the National Guard, which in fact did not introduce changes in the field of public law and legislation regarding public engagement in the national defense, and the National Guard still remained the only organisation for real public (only for citizens) engagement and alternative to CMS from the point of view of public law. Early 2017, the MoD announced that the country was returning to the concept of total or "comprehensive" defense, which was forgotten after joining the North Atlantic Treaty Organization (NATO). During this time, preparations for the establishment of high-readiness units in the National Guard Battalions continued (Nikers, 2017). At the beginning of 2018, the Ministry of Defense reported plans to expand the National Guard forces to 12,000 by 2027 . At that time, there were approximately 8,000 volunteers in the National Guard.

The first legal act approved by the Cabinet of Ministers in 2019, which sets a broader and more detailed policy within the public administration regarding public engagement in national defense, is the Informative Report on the Implementation of the Comprehensive National Defense System in Latvia (Informatīvais ziṇojums par visaptverošās sistēmas ieviešanu Latvijā, 2019). The report states that "the practical task of a comprehensive national defense system is to define specific tasks and roles for each governmental institution in national defense". The subsequent regulation of the Cabinet of Ministers instructs the MoD to establish and lead a working group for the development of a comprehensive protection system and determination of the further actions necessary.

The Informative Report consists of references regarding participation and responsibilities of individuals, explaining that "national defense applies to every resident of Latvia. (...) guaranteeing national defense is not only the duty of state authorities and administrations, but also the responsibility of each individual", but this document does not define specific obligations and responsibilities of individuals.

Information report is a declarative document that provides guidance to the $\mathrm{MoD}$ and public administration institutions. It describes the goals and objectives of the Comprehensive National Defense, such as "ensuring that state institutions, public organisations and citizens are ready to provide support to the National Armed Forces and perform vital functions for the further existence of society and the economy (...)". Simultaneously, it is stated that comprehensive national defense must "promote a culture of preparedness so that citizens prepare purposefully for the worst-case scenarios and are ready to support each other in their personal and social lives, thus providing a greater sense of security and consequent psychological resilience". In specifying these settings, 
reference is made to strengthening of the National Guard and the Youth Guard, which does not introduce any changes in the context of public law regarding engagement of citizens or the general public in national defense.

The comprehensive defense approach is strengthened in the National Defense Concept 2020 developed by the MoD and approved by the Saeima, in which even greater emphasis is placed on the responsibility and engagement of individuals and society in national defense (Par valsts aizsardzības koncepcijas apstiprināšanu, 2020).

This, too, is a conceptual document that, in the context of public law, does not introduce any substantial changes in the relationship among the state and citizens regarding the wider engagement of society and individuals in national defense. This document does not envisage a return to the CMS, but instead, suggests a more active and wider public engagement in national defense. Need to introduce compulsory national defense training in secondary schools in the 2024/2025 school year is mentioned. Mandatory implementation of national defense training is determined by the National Defense Training and Youth Guard Law, which entered into force on 5 January 2021 (Valsts aizsardzibas mācības un Jaunsardzes likums).

Article 23.5 of the National Security Law defines the concept of comprehensive national defense where (...) in the event of war, military invasion or occupation (...) the national armed forces, public administrations and local authorities, as well as natural and legal persons, shall take measures for the military and civil defense of the State and implement armed resistance, civil disobedience and non-cooperation with illegal civil administration bodies (Nacionālās drošības likums, 2001).

Regarding the Comprehensive National Defense System, despite the fact that obligations and rights regarding national defense are ruled in the National Security Law, obligations are defined only for citizens of the Republic of Latvia, the circle of subjects who have obligations and rights in the event of a state of emergency is expanded as of October 30, 2018, according to the Article $25^{1}$ of the same law. This provision in National Security Law (NSL) stipulates that in case of military invasion, when implementing comprehensive state defense policy, obligations and rights are determined not only for citizens of the Republic of Latvia, but for residents of the Republic of Latvia as a whole.

According to the NSL, the Latvian population is obliged to fulfill the tasks given by the National Armed Forces and the Allied Forces, as well as other state administration and local government institutions responsible for overcoming the state threat; not to cooperate with illegal administrative institutions and armed units of the aggressor, except in cases when the refusal to cooperate endangers the life or freedom of a person or his or her family members. At the same time, citizens have the right to exercise civil disobedience against illegal government institutions and the aggressor's armed units; to show armed resistance and provide support to members of civil disobedience and armed resistance, the NAF and allied forces.

There is currently no legislation in force to determine how these NSL regulations should be implemented, as well as to specify and regulate the fulfillment of obligations 
and rights imposed on citizens and the applicable liability in case of non-compliance with these obligations.

Public law also does not address the issue of engagement of all residents of the country in national defense, still extending these duties and rights only to citizens of the Republic of Latvia.

According to the comment of the State Secretary of the Ministry of Defense Jānis Garisons to "Latvijas Avize" on December 15, 2020, the right to make armed resistance can be exercised only in the ranks of the National Guard or professional military service, thus only Latvian citizens who have joined the National Guard, professional military service, or who are mobilised as reserve soldiers and reservists, which consequently do not apply to the entire population of Latvia (Drēziňš, 2020).

According to the Law on the National Guard, only Latvian citizens aged 18 to 55 can still join its ranks (Zemessardzes likums, 2010).

Regarding societal support for the army, the MoD State secretary in the interview indicates that this means ability of the population to "comprehend certain things outside of everyday life, out of the ordinary and report them to the relevant services, first and foremost - about the armed people of unknown origin". In the context of non-cooperation with the occupiers, each citizen "must understand for himself how far he can go - he should not endanger his own life or the lives of others".

These clarifications from MoD in the public give a greater understanding of the rights and obligations for the Latvian population within the context of NSL and the National Defense Concept 2020. From the perspective of the public law, the concept of "every citizen" and "every resident" engagement in the national defense is still not binding until mechanisms and procedures for compliance that include obligations and rights for citizens and residents, as well as obligations and rights of the public sector are set by law and subsequent governmental regulations. Latvian MoD took initiative to transform the policies towards societal engagement into national defense, at the same time leaving a legislator somehow behind in terms of adequate reflection of these policies into the legal acts and regulations. The Parliament has found itself playing a weak role reacting to the MoD's political course and never took a lead in expressing general political guide for the issue of societal engagement in national defense.

\section{Conclusions}

In the area of public law, there has been no significant change in public engagement in national defense, despite the willingness of the public, public administration and the legislative body to change the situation and the actual change in defense policy in response to international security challenges. This has been reflected in the National Defense Concepts in 2016 and 2020, as well as in the National Security Law. However, changes in this legislation have so far failed to provide a specific framework for public commitment to the engagement of individuals and society in national defense that would provide a comprehensive response to today's security challenges. 
Policy changes towards societal engagement in national defense itself came along "outside" pressure of "degrading" regional security environment, and reaction to the Russia's aggressive behavior, as the issue of public engagement in national defense has been on the agenda since Russia's aggression in Ukraine in 2014, and the dynamics of policy change in this regard are mainly related to the Ministry of Defense's policy initiatives, which are reflected in the respective policy documents.

While there has been a wide political debate on the form and nature of societal engagement into national defense, Latvian MoD is taking a lead in these policy matters, and the behavior of the legislator is mainly proactive or reactive. Though MoD is the governmental institution which is responsible for development and implementation of the national defense policy, the issue of societal engagement is domain which cannot be resolved within the narrow circles of public administration officials. This is a complex problem of "societal contract" with the state, where, for instance, important factors of public law should be carefully considered.

A legislator has to demonstrate its political will and communicate its vision with society, including wide spectrum of governmental and non-governmental institutions, think-tank community and academia, while setting agenda for such an important policy affecting lives of all Latvian citizens and residents. If MoD is taking a lead in these national policy matters and in certain regulations provides that, this is obligatory for every Latvian citizen and resident to engage into national defense, but the legislator fails to reflect and properly resolve these norms in the national legislation, it proves that balance of executive and legislative powers has been significantly distorted. It is necessary that public law in Latvia and subsequent policy documents and regulations clearly provide how responsibilities and obligations are divided among the state and society.

\section{Bibliography}

\section{Law}

1. Militārā dienesta likums: Latvijas Republikas likums. Latvijas Vēstnesis, Nr. 14, 25.07.2002.

2. Nacionālās drošības likums: Latvijas Republikas likums. Latvijas Vēstnesis, Nr. 3, 08.02.2001.

3. Nacionālo bruṇoto spēku likums: Latvijas Republikas likums. Latvijas Vēstnesis, Nr. 388/389, 24.11.1999.

4. Par valsts aizsardzības koncepcijas apstiprināšanu: Latvijas Republikas likums. Latvijas Vēstnesis, Nr. 117, 17.06.2016.

5. Par valsts aizsardzības koncepcijas apstiprināšanu: Latvijas Republikas likums. Latvijas Vēstnesis, Nr. 186, 25.09.2020.

6. Valsts aizsardzības mācības un Jaunsardzes likums: Latvijas Republikas likums. Latvijas Vēstnesis, Nr. 247A, 22.12.2020.

7. Valsts pārvaldes iekārtas likums: Latvijas Republikas likums. Latvijas Vēstnesis, Nr. 94, 21.06.2002.

8. Zemessardzes likums: Latvijas Republikas likums. Latvijas Vēstnesis, Nr. 82, 26.05.2010. 
Olevs Nikers. Bureaucratic Policy and Legal Aspects of

Societal Engagement in Latvian National Defense

\section{Literature}

9. Aberbach, J. D., \& Rockman B. A. (2000). In the web of Politics: Three Decades of the U.S. Federal Executive. Washington, DC: Brookings Institution Press, 56.

10. Cooper, A. D., Gvosdev, N. K., \& Blankshain J. D. (2018). Deconstructing the "Deep State": Subordinate Bureaucratic Politics in U.S. National Security. Foreign Policy Research Institute, 73.

11. Diena.lv. (2017). Mūrniece uzskata, ka Latvijā jāatjauno obligātais militārais dienests. Diena.lv. https://www.diena.lv/raksts/latvija/viedokli/murniece-uzskata-ka-latvija-jaatjauno-obligataismilitarais-dienests-14167688 [rev. 20.02.2021].

12. Drēziņš, A. (2020). Cik reāla ir okupācija? Kā rīkoties krīzes gadījumā? Saruna ar AM valsts sekretāru Jāni Garisonu. La.lv, December 25. https://www.la.lv/pretosanas-atbalsts-nesadarbosanas.

13. Easton, D. (1953). The Political System: An Inquiry into the State of Political Science. New York: Knopf.

14. Hammond, T. (2003). Veto Points, Policy Preferences, and Bureaucratic Autonomy in Democratic Systems. In Politics, Policy, and Organizations: Frontiers in the Scientific Study of Bureaucracy, ed. G. A. Krause, \& K. J. Meier. University of Michigan Press, p.185.

15. Informatīvais ziņojums par visaptverošās sistēmas ieviešanu Latvijā: Ministru kabineta informatīvais ziņojums. Ministru kabineta 08.01.2019. sēdes Nr. 1 protokllēmuma 29. \$., Latvijas Vēstnesis, Nr. 9, 14.01.2019.

16. Ingber, R. (2018). Bureaucratic Resistance and the National Security State. Iowa Law Review, 104, 139.

17. Krasner, S. D. (1984). Approaches to the State: Alternative Conceptions and Historical Dynamics. Comparative Politics, 16(2), 223-246.

18. Meisters, G. (2016). Jauna tendence: gada laikā ievērojami pieaudzis obligātā militārā dienesta atbalstītāju skaits. Skaties.lv, March 13. https://skaties.lv/zinas/latvija/sabiedriba/jauna-tendence-gada-laika-ieverojami-pieaudzis-obligata-militara-dienesta-atbalstitaju-skaits/.

19. Nikers, O. (2017). Latvia Pursues 'Total Defense' Concept, Rejects Conscription. Eurasia Daily Monitor. The Jamestown Foundation. https://jamestown.org/program/latvia-pursues-totaldefense-concept-rejects-conscription.

20. Nikers, O. (2019). The Role of NATO and Military Security Viewed from the Baltics Point of View. Institute of Eastern Europe Policy papers, 1/2019, 13-36.

21. Nikers, O., Tabuns, O. (2019). Institutional effects on defense and security cooperation - the case of the Baltic States. Security Forum University of Dabrowa Górnicza, 3 (2), 173-189.

22. Peters, B. G., \& Pierre, J. (2011). The Handbook of Public Administration, Sage, p.185

23. Pierson, P. and Skocpol T. (2002) Historical Institutionalism in Contemporary Political Science. In Political Science: State of the Discipline, ed. I. Katznelson and H. V. Milner. New York: Norton.

24. Rìta panorāma. (2016). Mūrniece: Latvijā jāatjauno diskusija par obligāto militāro dienestu, LSM. lv. https://www.lsm.lv/raksts/zinas/latvija/murniece-latvija-jaatjauno-diskusija-par-obligatomilitaro-dienestu.a176807/.

25. Thoenig, J.-C. (2011). Institutional Theories and Public Institutions: New Agendas and Appropriateness. In Handbook of Public Administration, ed. G. Peters and J. Pierre. London, Sage, pp.101-185.

26. Thoenig, J.-C. (2005). Territorial Administration and Political Control. Decentralization in France. Public Administration, No. 83, pp.685-708. 